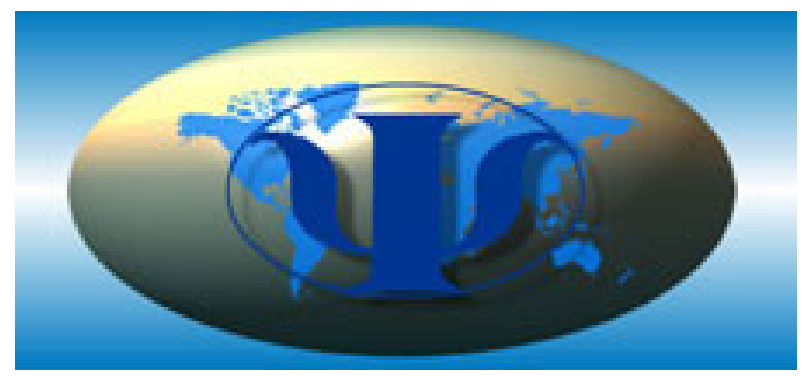

Putting the Best Leaders in the White House: Personality, Policy, and Performance Author(s): Dean Keith Simonton

Source: Political Psychology, Vol. 14, No. 3 (Sep., 1993), pp. 537-548

Published by: International Society of Political Psychology

Stable URL: http://www.jstor.org/stable/3791713

Accessed: 19/07/2011 13:40

Your use of the JSTOR archive indicates your acceptance of JSTOR's Terms and Conditions of Use, available at http://www.jstor.org/page/info/about/policies/terms.jsp. JSTOR's Terms and Conditions of Use provides, in part, that unless you have obtained prior permission, you may not download an entire issue of a journal or multiple copies of articles, and you may use content in the JSTOR archive only for your personal, non-commercial use.

Please contact the publisher regarding any further use of this work. Publisher contact information may be obtained at http://www.jstor.org/action/showPublisher?publisherCode=ispp.

Each copy of any part of a JSTOR transmission must contain the same copyright notice that appears on the screen or printed page of such transmission.

JSTOR is a not-for-profit service that helps scholars, researchers, and students discover, use, and build upon a wide range of content in a trusted digital archive. We use information technology and tools to increase productivity and facilitate new forms of scholarship. For more information about JSTOR, please contact support@ jstor.org. 


\title{
Putting the Best Leaders in the White House: Personality, Policy, and Performance
}

\author{
Dean Keith Simonton \\ Department of Psychology, University of California, Davis
}

This paper discusses what political psychology might have to offer in making it more likely that the best leaders might become Presidents of the United States. An analytical framework outlines some of the more likely contributions of the political psychologist to the electoral process. This framework defines how the leader's personality, likely policy preferences, and political performance may be objectively inferred from the available biographical and content analytical data. After reviewing examples of relevant empirical research, the paper closes with a discussion of the assets and liabilities of this analysis.

KEY WORDS: political leadership; presidential elections; personality; performance; policy; political psychology.

\section{THE ISSUE}

There may be something a little arrogant about a psychologist's addressing the subject of this essay. Even the expertise of a political psychologist may simply be in the wrong place. After all, as citizens of a democracy, the first task before us is to decide our stands on the critical issues of the day. What should be the best energy policy for the nation? How should we best deal with the emerging nations of Eastern Europe? Is there a workable compromise between free trade and American jobs? Should the federal government take a more active role in reversing the tragic state of education and health care in this country? Where should the United States channel its limited resources to solve problems of pollution and environmental degradation? What big-tag programs in the budget of the Department of Defense can we cut without harming our nation's standing in the world? Once we have studiously answered these and a myriad other 
questions, we then search among the prospective presidential candidates for the one whose policies represent the maximum fit.

Who needs the pundit in all this? To be sure, we may wish to consult economists to determine the most workable plan for increasing jobs, lowering inflation, or rectifying the trade imbalance. And we may ask ecologists, educators, diplomats for advice on other issues where those consultants can claim some special wisdom. But where does the political psychologist come in? How can a psychological perspective possibly shed light on the best leader for the job? Figure 1 provides the framework for an answer.

This figure outlines the complex process that we must really go through to evaluate candidates for the presidency. According to this scheme, we judge presidential hopefuls on more than just their stands on the issues. We also seek those candidates who exhibit a superior level of leadership. It does no good to elect someone who represents the will of the American people if that incumbent cannot execute that will after Inauguration Day. Closely related to this performance question is the matter of character. In any given election, a particular personality profile may best fit the needs of the nation. For example, sometimes the search for a strong moral character takes precedence over policy and performance criteria when we decide for whom to vote. Hence, in evaluating who is the

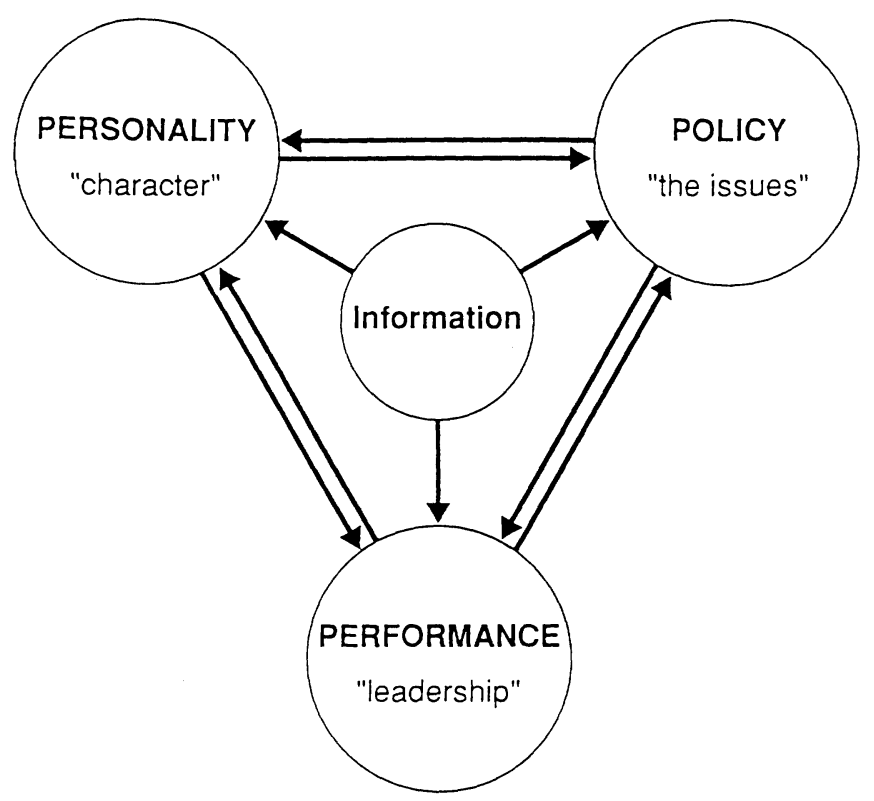

Fig. 1. The inferential framework for judging presidential candidates. 
best politician for the job, we often weigh the diverse trade-offs between personality, policy, and performance.

However, as figure 1 implies, these three criteria do not constitute completely independent judgments. Rather, the three components of the evaluation process may interact in complex ways. Some character traits go better with certain policy stands or performance expectations. For instance, our assessments of a candidate's willingness to solve the problem of the homeless may depend in part on our perceptions of how compassionate we perceive him or her to be. Similarly, we may feel that certain character traits may enhance a candidate's prospects for effective performance. Or we may sense that certain policy positions may be so controversial that they might prevent a candidate from doing a capable job in the White House. Thus, we will constantly make inferences back and forth between these separate judgmental criteria.

Figure 1 suggests one further nicety: We voters usually lack the direct knowledge needed to gauge the merits of rival candidates. Because few of us know the candidates personally, our judgments of character must be conjectural. Inferences about stands on policy are also less than direct. Admit it! Most of us read a few magazine and newspaper articles, catch some newscasts and specials, glance over some campaign literature, and then cast our ballots in November. As a consequence, most of us could not claim that our perceptions of the candidates' positions correspond perfectly with their actual attitudes.

Our appraisals of performance are often even more conjectural and approximate. Only when an incumbent runs for reelection can we have a secure idea about the candidate's actual capabilities in that unique position. Yet this tells us nothing about whether the challenger might not do a better job in the Oval Office. Seldom do we encounter the situation where a former president runs against a sitting president. The last time this happened was when Teddy Roosevelt ran against Taft in 1912 - and they both lost to newcomer Wilson! Therefore, when we make our judgments we frequently draw conclusions under very limited information. It matters not whether this dearth of data is due to excessive laziness or restricted access. The significant fact is that our assessments are surmises.

I argue that the complex process diagrammed in figure 1 offers political psychologists just the opportunity they need. They may lack the expertise to make recommendations about optimal policy, but they can address everything else contained in the graph. To develop this argument, let me provide a brief overview of some applicable research. I obviously cannot do justice to the rich literature on this subject. This is better summarized in Why presidents succeed: A political psychology of leadership (Simonton, 1987b; see also Simonton, 1990a). Still, I hope to mention enough findings to show that political psychologists can contribute something valuable to the electoral process. At least we might raise the odds, however slightly, that the best candidate becomes the next incumbent. 


\section{AN OVERVIEW}

If there is anything definite that we can say about the discipline of political psychology, it is that we can say nothing definite-except about its subject matter. Its practitioners hail from many disciplines, including psychology, psychiatry, political science, and history. Not surprisingly, the approaches to even so specific a question as the presidency are equally diverse. Some favor single-case studies, others large $N$ investigations. Some prefer qualitative methods and others quantitative techniques. Some focus on leaders, others on activists, and yet others on the masses. Because I cannot possibly cover the full range of approaches, I will concentrate on those strategies that best fit my own professional preoccupations. In particular, I focus on presidential studies that apply quantitative methods and nomothetic principles to data on multiple presidents. Briefly put, historiometric inquires shall command our focal attention (Simonton, 1990b).

Many researchers have tired to identify biographical data that would enable us to infer a candidate's standing on the three criteria of personality, policy, and performance. In other words, if we have access to an accurate biography of a presidential aspirant, we can make some judgments about kind of incumbent he or she would make. For instance, birth order has been repeatedly connected to the type of leadership a president is most likely to display, including how the executive responds in international crises (Stewart, 1977, 1991). Birth order even relates to the amount of charisma an incumbent exhibits in office (Simonton, 1988b). A candidate's physical height can determine both the chances of election and reelection to the White House and the odds of performing well in the Oval Office (Holmes \& Elder, 1989; McCann, 1992; Simonton, 1981, 1986b). The level of formal education attained influences, via a backward-J curve, the inflexibility that a president projects while in office (Simonton, 1983). And the president's usage of the veto power is contingent on his prior experience as a member of Congress (Lee, 1975). Furthermore, empirical research can often help us decide what information to ignore when evaluating various White House aspirants. For example, even though we sometimes think a politician's age germane to predicting presidential behavior (Murphy, 1984), historiometric inquiries show that this variable has no genuine value in predicting presidential performance (Simonton, 1986b, 1986c, 1988b; cf. Simonton, 1988a).

These relationships - but a few of many that might be enumerated-show that readily accessible information can be used to anticipate a candidate's prospective presidency. Moreover, these factual clues can be complemented by careful content analyses of campaign speeches. Several studies have shown that addresses, letters, diplomatic communiques, press interviews, and debate transcripts can revel important aspects of a politician's cognitive style and motivational disposition (e.g., Gottschalk, Uliana, \& Gilbert, 1988; Hermann, 1980; 
Tetlock, 1983; Winter, 1982, 1987; Zullow \& Seligman, 1990). These personality factors often have grave consequences for an incumbent's policy and performance activities.

This last point actually bring us to an important domain of empirical findings. To some extent, knowledge about how a political actor rates on one part in figure 1 provides hints about the corresponding ratings on the other components. Consider first the inferential nexus between personality and policy. Presidents low in integrative complexity, which gauges sophistication in information processing, may be more likely to adopt simplistic orientations towards other nations, as manifested in such policy stances as isolationism (Tetlock, 1981). On the motivational side, three elementary motives have been associated with the proclivity to enter into military conflict, the willingness to negotiate armslimitation agreements, and so forth (Wendt \& Light, 1976; Winter, 1987; Winter \& Stewart, 1977). In a like vein, preferred patterns of interpersonal relationships-especially dispositions towards dominance and extroversiontend to affect a president's orientation toward foreign powers (Etheredge, 1978). For example, politicians who like to lord it over subordinates advocate foreign policies where the United States assumes a domineering place in world politics.

When we turn to performance criteria, the impress of personality is even more pronounced. Presidents gifted with superior integrative complexity, for example, are far better decision-makers during international crises (Suedfeld \& Tetlock, 1977; Suedfeld, Tetlock, \& Ramirez, 1977), while whose who score higher on flexibility can claim better odds of working well with Congress ( $\mathrm{Si}$ monton, 1986c, 1987a). Broad intellectual brilliance is an excellent predictor of whether an incumbent will go down in history as a great president (McCann, 1992; Simonton, 1986c, 1988b, 1991c, in press). Finally, if the American electorate wishes to avoid a president who provokes great controversy, it would do well to spurn a candidate with a very distinctive personality profile. A candidate high in creativity, achievement drive, forcefulness, pettiness, and inflexibility but low in moderation, friendliness, and wit is most prone to rub observers of the political scene the wrong way (Simonton, 1986c, 1988b).

Again, these results represent only a smattering of the many findings that we might draw upon when engaged in the inferential process diagrammed in figure 1 . These findings were all founded on a systematic and rigorous examination of actual data on presidential personality, policy, and performance. Moreover, many of the central discoveries have received theoretical and empirical confirmation in other areas of political leadership besides the American chief executive (see, e.g., House, Spangler, \& Woycke, 1991; Simonton, 1984, 1986a, 1991b; Stewart, 1977, 1991; Winter, Hermann, Weintraub, \& Walker, 1991 a, 1991b). It renders our inferences more secure if we can believe there are certain characteristics of outstanding political leaders that transcend specific national cultures and constitutional norms. This implies that what makes for 
presidential success may not change capriciously from election year to election year (see Simonton, 1986b, 1986c).

\section{SOME COMPLICATIONS}

After praising our expertise in such glowing terms, why spoil things by inserting a few inconvenient qualifications? Honesty dictates that I must. Several crucial considerations force us to restrain our enthusiasms. Weigh the following five items:

1. The amount of variance explained by our prediction equations is seldom overwhelming. That is, a significant proportion of the variation in any criterion of political success is often left unaccounted for in even equations containing numerous predictors (Simonton, 1990b). Only in the case of presidential greatness ratings can we say that we can predict more than $80 \%$ of the variance (McCann, 1992; Simonton, 1986c, 1991c, in press). For other criteria-and especially for more objective, behavioral gauges of achievement in the Oval Office-the variation explained can shrink to less respectable figures. For instance, we can accurately predict only around one-half to two-thirds of the incumbent's effective use of the executive veto (Copeland, 1983; Lee, 1975; but see Rohde \& Simon, 1985). Although effect sizes even smaller than these can still have important consequences (Abelson, 1985; Rosenthal \& Rubin, 1979), the fact remains that our prediction equations must be leaving a lot out. Hence, any forecast about the relative merits of rival candidates must be tempered with a healthy dose of skepticism. This temperance is especially mandatory when the competitors are rather close in qualifications for the office. We don't know enough to make fine distinctions, but only gross judgments.

2. I have been dishonest: Usually equations that predict presidential success attain respectable levels of predictive power by incorporating many situational variables (Kenney \& Rice, 1988; Nice, 1984; Rosenstone, 1983; Simonton, 1986a, 1986b, 1991c). For example, in anything having to do with legislative performance, we almost invariably discover that one predictor accounts for more variance than any other-how sizable is the majority enjoyed by the incumbent's political party (e.g., Lee, 1975; Copeland, 1983; Simonton, 1986b, 1987a). Especially nowadays, when the president's coattails may be too short to guarantee that his party will be swept into the House and Senate (cf. Born, 1984), this factor imposes a constraint on the incumbent's power that is simply beyond the incumbent's control. Likewise, the incumbent's legislative influence is partly contingent on his popularity in the polls (e.g., Bond \& Fleisher, 1984; Page \& Shapiro, 1984; Zeidenstein, 1985), yet this circumstance is itself vulnerable to a whole host of extraneous inputs, including unexpected international crises (Hibbs, 1982; Kernell, 1978; Mueller, 1970, 1973). In some instances, an in- 
cumbent's performance will be totally at the mercy of situational caprice. A good illustration is the vice-presidential succession effect (Simonton, 1985b). Those "accidental" presidents who succeed to the office upon the death or resignation of their predecessor are inclined to perform miserably. They have more of their vetoes overturned by Congress and see more Cabinet and Supreme Court appointments rejected by the Senate. Yet we have abundant reason to believe that these negative results are situational (Simonton, 1985b, 1986c, 1988b). Besides the fact that accidental presidents do not systematically differ on any relevant personality traits, biographical background variables, or political experiences, their disadvantage only holds for their nonelected term in office. As Teddy Roosevelt, Coolidge, Truman, and Lyndon Johnson showed, it is possible to overcome the stigma if given a second chance under the people's direct mandate.

3. It gets worse than this: It's not just that situational factors exhibit such a comprehensive influence, but they can also moderate the impact of the individual factors that are the primary focus of political psychologists. Thus, we often find the operation of Individual X Situational Interaction Effects. For instance, the effect of birth order on presidential success may hinge on the political zeitgeist (Stewart, 1977). First-borns may have the advantage in times of international crisis and war, yet the middle-borns may enjoy the edge when the circumstances favor peaceful reconciliation. A second illustration is perhaps more dramatic: the Johnson-Wilson effect (Simonton, 1987a). This concerns the relationship between a personality trait - inflexibility - and a performance outcome - successful use of the executive veto. This relationship varies according to how many supporters the incumbent can claim on Capitol Hill. When the president has ample support, personality plays a minimal role in effective use of the veto power. Yet when the president's party is in the minority in Congress, the inability to adopt flexible tactics in the give-and-take world of legislation becomes a major liability. The interaction effect is named after Andrew Johnson and Woodrow Wilson, two executives who were quite competent when conditions were auspicious but who fell apart whenever they had to deal with strong opposition. How can we possibly anticipate whether circumstances will abruptly alter, converting a once competent incumbent into a nincompoop?

4. Even when we can somehow hold the contextual variables constant, and thereby isolate personality traits as predictors, we are not completely off the hook. No one set of psychological factors allows us to predict presidential success across all critical criteria. For example, intellectual brilliance has a most ambivalent relationship with leadership: It may enable a president to go down in history as a great chief executive, yet such incumbents are not necessarily very popular with the American people (McCann, 1992; Simonton, 1986b; see also Simonton, 1985a, 1991b). They often enter the White House with extremely narrow vote margins. David Winter has uncovered even better instances in his studies of the power, affiliation, and achievement motives (Winter, 1987; Winter 
\& Stewart, 1977; see also House, Spangler, \& Woycke, 1991; Wendt \& Light, 1976). A certain motivational profile may be conducive to success by one criterion but absolutely antithetical to success by another criterion. Thus, affiliative presidents are more likely to negotiate arms limitation agreements, but they are also more likely to have scandals break out in their administrations. Powerdriven presidents may intimidate other nations from resorting to military force, yet they may also rely too much on military might themselves - and they may become the targets of assassination attempts! Hence, we are once more forced to ask American voters to set priorities regarding the type of principles and activities they wish to emanate from 1600 Pennsylvania Avenue. Only after that decision is made can the political psychologist specify the optimal personality profile for achieving that desideratum.

5 . We may be guilty of some excessive idealism in our conception of the American voter. We have assumed that citizens can engage in a rational inference process such as that outlined in figure 1. Given the accumulated body of "scientific knowledge" and a set of policy priorities, the voter supposedly makes an informed, even wise, choice come November. Yet all the work on political cognition suggests that people are not nearly so sophisticated (see Kinder \& Fiske, 1986; Lau \& Sears, 1986). We often act as "cognitive misers" who take inferential shortcuts to minimize the amount of effort necessary to acquit ourselves of our civil responsibilities. Rather than pursue an intellectually expensive "bottom-up" strategy of absorbing all the data and then drawing a conclusion, we frequently begin with a simplified leader schema, and then operate according to a "top-down" strategy that overlooks important features of the available information. Moreover, there seem to exist irrevocable limits on (a) the maximum amount of information we can assimilate and (b) the maximum complexity of functional relationships we can accommodate (Faust, 1984; Meehl, 1954). In particular, most of us can only handle about a half-dozen predictors, which we then manipulate in a simple additive fashion. Interactions-effects and curvilinear functions are beyond us. And it's not just the average Joe or Jane on the street who has problems exhibiting conceptual complexity. Even experts operate according to simplistic information-processing principles (see, e.g., Simonton, 1986a, 1987b). So, how can we expect anyone really to benefit from the expertise stockpiled in the volumes of Political Psychology or other scientific journals?

I actually have an answer that may efface the pessimistic tone of this rhetorical question. Perhaps we can end this essay on an upbeat message after all, however visionary my speculations may become. The solution may lie with future advances in computer technology, especially artificial intelligence software. Already it is evident that computers can outguess human experts in certain types of clinical assessments (Dawes, Faust, \& Meehl, 1989). Unlike the puny human brain, we can easily program computers (a) to consider all the appropriate 
information no matter how rich and (b) to combine these data in as complex a manner as required by the inferential problem. With recent developments in artificial intelligence, computers can become increasingly like brilliant yet devoted sidekicks who help us out with expert advice. I am not speaking of the spell checkers or even grammar checkers that have become an adjunct of word processing. Rather, I am thinking of programs like TETRAD that actively search for optimal causal structures in a correlation matrix (Glymour, Scheines, Spirtes, \& Kelley, 1987; for application see Simonton, 1991a). Or, better yet, we have the fascinating example of STATISTICAL NAVIGATOR PROFESSIONAL ${ }^{\mathrm{TM}}$, which serves as a personal statistical consultant (Brent, Mirielli, Detring, \& Ramos, 1991). Inspired by these programs and the development of expert systems like MYCIN (Buchanan \& Shortliffe, 1984), I conceive the following (admittedly futuristic) scenario.

It's the night before Election Day. A week earlier you received in the mail an optical disk that contains a computer program called VOTER HELPER ${ }^{\text {TM }}$ (Simonton, n.d.). You could've popped the disk in your personal computer earlier, but like tax preparation, you put it off until the last minute. Still, not wanting to go to the polls as an irrational voter, you appeal to this software for advice. It asks you some basic questions, like where you live, to determine which specific ballot you'll be using. It then probes you about your position on the key issues of the day. Besides rating your attitudes along the usual Likert scale, you must assign each issue a priority according to, say, the 1-10 Bolero scale. Next you will encounter a group of questions about the type of leadership style you most prefer to have in office, along with another set of queries about what performance criteria you value most. Do you want a charismatic chief executive? Do you like a president who is an effective legislator? Do you prefer someone in the Oval Office who will maintain American diplomatic prestige on the world scene? Finally, at 1:47 a.m., you come across the last menu. You can either start over, double-check your entries, or press the print button. Exhausted but satisfied, you go for it. Your laser printer purrs. And out comes a booklet suggesting how you should cast your ballot after work-from President of the United States right down to Municipal Proposition C. The last section of the printout is the best: This rates the presidential candidates on global assessments of personality, policy, and performance, plus an overall probability that each aspirant will become a really good president.

This describes VOTER HELPER 1.0. Version 2.0 of the program will take advantage of your PC's modem to convey your preferences directly to the ballot counter computer. Then . . O.K., O.K.! I know, this is a long time off. It may never even happen. But the only way we are going to get closer is for the political psychologist to build the expertise that will eventually go into these "political pundit systems." We must amass a huge inventory of highly pertinent empirical results. Let's get busy! 


\section{REFERENCES}

Abelson, R. P. (1985). A variance explanation paradox: When a little is a lot. Psychological Bulletin, 97, 129-133.

Bond, J. R., \& Fleisher, R. (1984). Presidential popularity and congressional voting: A reexamination of public opinion as a source of influence in Congress. Western Political Quarterly, 37, 291-306.

Born, R. (1984). Reassessing the decline of presidential coattails: United States House elections from 1952-80. Journal of Politics, 46, 60-79.

Brent, E. E., Jr., Mirielli, E. J., Jr., Detring, E., \& Ramos, F. (1991). Statistical Navigator Professional $^{\mathrm{TM}}$ : User's guide and reference manual version 1.0. Columbia, MO: Idea Works.

Buchanan, B. G., \& Shortliffe, E. H. (Ed.). (1984). Rule-based expert systems: The MYCIN experiments of the Stanford Heuristics Programming Project. Reading, MA: Addison-Wesley.

Copeland, G. W. (1983). When Congress and the President collide: Why presidents veto legislation. Journal of Politics, 45, 696-710.

Dawes, R. M., Faust, D., \& Meehle, P. E. (1989). Clinical versus actuarial judgment. Science, 243, $1668-1674$.

Etheredge, L. S. (1978). Personality effects on American foreign policy, 1898-1968: A test of interpersonal generalization theory. American Political Science Review, 78, 434-451.

Faust, D. (1984). Limits of scientific reasoning. Minneapolis: University of Minnesota Press.

Gottschalk, L. A., Uliana, R., \& Gilbert, R. (1988). Presidential candidates and cognitive impairment measured from behavior in campaign debates. Public Administration Review, 48, 613619.

Glymour, C., Scheines, R., Spirtes, P., \& Kelley, K. (1987). Discovering causal structure: Artificial intelligence, philosophy of science, and statistical modeling. Orlando: Academic Press.

Hermann, M. G. (1980b). Explaining foreign policy using personal characteristics of political leaders. International Studies Quarterly, 24, 7-46.

Hibbs, D. A. (1982a). The dynamics of political support for American presidents among occupational and partisan groups. American Journal of Political Science, 26, 312-332.

Holmes, J. E., \& Elder, R. E. (1989). Our best and worst presidents: Some possible reasons for perceived performance. Presidential Studies Quarterly, 19, 529-557.

House, R. J., Spangler, W. D., \& Woycke, J. (1991). Personality and charisma in the U.S. presidency: A psychological theory of leader effectiveness. Administrative Science Quarterly, 36, 364396.

Kenney, P. J., \& Rice, T. W. (1988). The contextual determinants of presidential greatness. Presidential Studies Quarterly, 18, 161-169.

Kernell, S. (1978). Explaining presidential popularity: How ad hoc theorizing, misplaced emphasis, and insufficient care in measuring one's variables refuted common sense and led conventional wisdom down the path of anomalies. American Political Science Review, 72, 506-522.

Kinder, D. R., \& Fiske, S. T. (1986). Presidents in the public mind. In M. G. Hermann (Ed.), Political psychology: Contemporary problems and issues (pp. 193-218). San Francisco: JosseyBass.

Lau, R. R., \& Sears, D. O. (Ed.). (1986). Political cognition: The 19th Annual Carnegie Symposium on Cognition. Hillsdale, NJ: Erlbaum.

Lee, J. R. (1975). Presidential vetoes from Washington to Nixon. Journal of Politics, 37, 522-546.

Meehl, P. (1954). Clinical versus statistical prediction: A theoretical analysis and a review of the evidence. Minneapolis: University of Minnesota Press.

Mueller, J. E. (1970). Presidential popularity from Truman to Johnson. American Political Science Review, 64, 18-34.

Mueller, J. E. (1973). War, presidents and public opinion. New York: Wiley.

$\rightarrow$ Murphy, A. B. (1984). Evaluating the presidents of the United States. Presidential Studies Quarterly, $14,117-126$.

Nice, D. C. (1984). The influence of war and party system aging on the ranking of presidents. Western Political Quarterly, 37, 443-455. 
Page, B. I., \& Shapiro, R. (1984). Presidents as opinion leaders: Some new evidence. Policy Studies Journal, 12, 649-661.

Rohde, D. W., \& Simon, D. M. (1985). Presidential vetoes and congressional response: A study of institutional conflict. American Journal of Political Science, 29, 397-427.

Rosenthal, R., \& Rubin, D. B. (1979). A note on percent variance explained as a measure of the importance of effects. Journal of Applied Social Psychology, 9, 395-396.

Simonton, D. K. (1981). Presidential greatness and performance: Can we predict leadership in the White House? Journal of Personality, 49, 306-323.

Simonton, D. K. (1983). Formal education, eminence, and dogmatism: The curvilinear relationship. Journal of Creative Behavior, 17, 149-162.

Simonton, D. K. (1984). Leaders as eponyms: Individual and situational determinants of monarchal eminence. Journal of Personality, 52, 1-21.

Simonton, D. K. (1985a). Intelligence and personal influence in groups: Four nonlinear models. Psvchological Review, 92, 532-547.

Simonton, D. K. (1985b). The vice-presidential succession effect: Individual or situational basis? Political Behavior, 7, 79-99.

Simonton, D. K. (1986a). Dispositional attributions of (presidential) leadership: An experimental simulation of historiometric results. Journal of Experimental Social Psychology, 22, 389418.

Simonton, D. K. (1986b). Presidential greatness: The historical consensus and its psychological significance. Political Psychology 7, 259-283.

Simonton, D. K. (1986c). Presidential personality: Biographical use of the Gough Adjective Check List. Journal of Personality and Social Psychologv. 51, 149-160.

Simonton, D. K. (1987a). Presidential inflexibility and veto behavior: Two individual-situational interactions. Journal of Personality, 55, 1-18.

Simonton, D. K. (1987b). Why presidents succeed: A politicalpsychology of leadership. New Haven, CT: Yale University Press.

Simonton, D. K. (1988a). Age and outstanding achievement: What do we know after a century of research? Psychological Bulletin, 104, 251-267. Simonton, D. K. (1988b).

Presidential style: Personality, biography, and performance. Journal of Personality and Social Psychology, 55, 928-936.

Simonton, D. K. (1990a). Personality and politics. In L. A. Pervin (Ed.), Handbook of personality theory and research (pp. 670-692). New York: Guilford.

Simonton, D. K. (1990b). Psychology, science, and history: An introduction to historiometry. New Haven, CT: Yale University Press.

Simonton, D. K. (199la). Latent-variable models of posthumous reputation: A quest for Galton's $G$. Journal of Personality and Social Psychology, 60, 607-619.

Simonton, D. K. (1991b). Personality correlates of exceptional personal influence: A note on Thorndike's (1950) creators and leaders. Creativity Research Journal, 4, 67-78.

Simonton, D. K. (1991c). Predicting presidential greatness: An alternative to the Kenney and Rice Contextual Index. Presidential Studies Quarterly, 21, 301-305.

Simonton, D. K. (in press). Presidential greatness and personality: A response to McCann (1992). Journal of Personality and Social Psychology.

Simonton, D. K. (n.d.). Voter Helper ${ }^{\mathrm{TM}}$ : User's guide, reference manual, and tutorial. Fantasy in preparation.

Stewart, L. H. (1977). Birth order and political leadership. In M. G. Hermann (Ed.), The psychological examination of political leaders (pp. 205-236). New York: Free Press.

Stewart, L. H. (1991). The world cycle of leadership. Journal of Analytical Psychology, 36, 449459.

Suedfeld, P., \& Tetlock, P. E. (1977). Integrative complexity of communications in international crises. Journal of Conflict Resolution, 21, 169-184.

Suedfeld, P., Tetlock, P. E., \& Ramirez, C. (1977). War, peace, and integrative complexity. Journal of Conflict Resolution, 21, 427-442.

Tetlock, P. E. (1981). Personality and isolationism: Content analysis of senatorial speeches. Journal of Personalitv and Social Psvchologv. 41. 737-743. 
Tetlock, P. E. (1983). Cognitive style and political ideology. Journal of Personality and Social Psychology, 45, 118-126.

Wendt, H. W., \& Light, P. C. (1976). Measuring "greatness" in American presidents: Model case for international research on political leadership? European Journal of Social Psychology, 6, 105109.

Winter, D. G. (1980). An explanatory study of the motives of southern African political leaders measured at a distance. Political Psychology, 2, 75-85.

Winter, D. G. (1982). Motivation and performance in presidential candidates. In A. J. Stewart (Ed.), Motivation and society: A volume in honor of David C. McClelland (pp. 244-273). San Francisco: Jossey-Bass.

Winter, D. G. (1987). Leader appeal, leader performance, and the motive profiles of leaders and followers: A study of American presidents and elections. Journal of Personality and Social Psychology, 52, 196-202.

Winter, D. G., Hermann, M. G., Weintraub, W., \& Walker, S. G. (1991a). The personalities of Bush and Gorbachev at a distance: Procedures, portraits, and policies. Political Psychology, 12, 215245.

Winter, D. G., Hermann, M. G., Weintraub, W., \& Walker, S. G. (1991b). The personalities of Bush and Gorbachev at a distance: Follow-up on predictions. Political Psychology, 12, 457-464.

Winter, D. G., \& Stewart, A. S. (1977). Content analysis as a technique for assessing political leaders. In M. G. Hermann (Ed.), The psychological examination of political leaders (pp. 2761). New York: Free Press.

$\rightarrow$ Zeidenstein, H. G. (1985). President's popularity and their wins and losses on major issues in Congress: Does one have greater influence over the other? Presidential Studies Quarterly, 15, 287-300.

Zullow, H. M., \& Seligman, M. E. P. (1990). Pessimistic rumination predicts defeat of presidential candidates, 1900 to 1984. Psychological Inquiry, 1, 52-61. 